УДК 81'373’06

DOI https://doi.org/10.26661/2414-9594-2020-2-14

\title{
ПОНЯТТЯ МОТИВАЦІЇ МОВНИХ ОДИНИЦЬ ЯК СПІВВІДНОШЕННЯ МОВНОГО ЗНАКА ТА ЗНАЧЕННЯ
}

\author{
Крижко О. А. \\ кандидат філологічних наук, дочент, \\ дочент кафедри української мови та славістики \\ Бердянський держсавний педагогічний університет \\ вул. Шмідта, 4, Бердянськ, Запорізька область, Украӥна \\ orcid.org/0000-0002-5581-5915 \\ elenakryzhko8@gmail.com
}

\begin{abstract}
Ключові слова: мотивація, мовний знак, концепт, знакове значення, семіозис, денотат, сигніфікат, структура, система.
\end{abstract}

У статті розглядається проблема мотивації мовних одиниць як співвідношення мовного знака та значення. Зокрема, акцентується увага на специфіці самого мовного знака, яка зумовлена передусім його асиметричною природою, оскільки будь-які фактори зміни завжди призводять до зсуву відношень між означуваним і означувальним. Крім того, аналізуються основні властивості й ознаки мовного знака, подаються різноманітні підходи до визначення типів семантичних знакових відношень, виділяються асиметричні відношення у словесному знакові (нульова асиметрія, синтагматична асиметрія, парадигматична асиметрія), вказуються наслідки асиметрії словесного знака.

У дослідженні зазначається, що словесні знаки як категорії лексичної семантики одночасно належать і семантичній структурі - одній з окремих субструктур загальної структури мови, і рівню лексики. Як семантичні категорії вони базуються на семасіологічних ознаках, а як категорії лексичного рівня мають також формальне вираження, тобто категоріям лексичної семантики властиве змістовно-формальне відбиття. Необхідно розрізняти семасіологічний і ономасіологічний підхід до їх вивчення, тобто кожну з категорій можна визначити у змістовому та значеннєвому планах. Із семасіологічного погляду гомосемні одиниці - це омолексемні полісемеми, з ономасіологічного - полісемемні омолексеми, а гетерогенні - полілексемні омосемеми й омосемемні полілексеми.

3 погляду співвідношення словесного знака й лексичного значення категорії лексичної семантики визначаються в аспекті топологічної / диференційної лінгвістики, проте структурний підхід до значення ще повністю не відповідає на питання взаємозумовленості знака та значення. Значення виникає в тих випадках, коли існують концептуальні зв'язки певного виду, що поєднують концепти як дискретні змістові сутності свідомості. Ці зв'язки можуть бути імплікаційними, порівняльнокласифікаційними та семіотичними (знаковими).

Одним з основних положень лінгвістичної теорії є принцип довільності мовного знака, тобто як неумотивованість, як відсутність зв'язку між означувальним і означуваним, однак у системі мови мовний знак виявляється відносно мотивованим. 


\title{
THE CONCEPT OF MOTIVATION OF LANGUAGE UNITS AS A RATIO OF LANGUAGE SIGN AND MEANING
}

\author{
Kryzhko O. A. \\ Candidate of Philological Sciences, Associate Professor, \\ Associate Professor at the Department of Ukrainian Language and Slavic Studies \\ Berdyansk State Pedagogical University \\ Shmidta str., 4, Berdyansk, Zaporizhzhia region, Ukraine \\ orcid.org/0000-0002-5581-5915 \\ elenakryzhko8@gmail.com
}

Key words: motwation, language sign, concept, sign meaning, denotate, significate, structure, system.
The article considers the problem of motivation of language units as a ratio of language sign and meaning. In particular, attention is focused on the specifics of the linguistic sign itself, which is due to its asymmetric nature, because any factors of change always lead to a shift in the relationship between the signified and the signifier.

The main properties and features of the language sign are analyzed, various approaches to determining the types of semantic sign relations are given, asymmetric relations in the verbal sign are distinguished (zero asymmetry, syntagmatic asymmetry, paradigmatic asymmetry), the consequences of verbal sign asymmetry are indicated.

The study notes that verbal signs as a category of lexical semantics simultaneously belong to the semantic structure - one of the individual substructures of the general structure of language - and the level of vocabulary. As semantic categories, they are based on semasiological features, and as categories of the lexical level they also have a formal expression, so the categories of lexical semantics are characterized by semantic-formal reflection. It is necessary to distinguish between semasiological and onomasiological approach to their study, each of the categories can be defined in terms of content and meaning. From the semasiological point of view, homosemous units are homolexemic polysemes, from the onomasiological point of view, they are polysemous homolexes, and heterogeneous units are polylexemic homosemes and homosemous polylexes.

From the point of view of the ratio of the verbal sign and the lexical meaning, the categories of lexical semantics are determined in the aspect of topological / differential linguistics. However, the structural approach to meaning does not fully answer the question of the interdependence of sign and meaning. Meaning arises when there are conceptual relationships of a certain type, combining semantic concepts as discrete nature of consciousness. These relationships can be implicit, comparative and semiotic.

One of the main tenets of linguistic theory is the principle of the arbitrariness of a linguistic sign, as unmotivated, the lack of connection between the signifier and the signified, but in the language system the linguistic sign was relatively motivated.
Постановка проблеми. Розв'язання проблеми мотивації пов'язане насамперед із питанням про співвідношення словесного знака та значення, яке остаточно в мовознавчій науці ще не розв'язане. Трактування мовного знака як єдності того, що позначає, і того, що позначають, традиційно в лінгвістиці уточнюють положенням про асиметрію такої єдності (В.Г. Гак [1], С.О. Карцевський [2], О.О. Кретов [3] та ін.).
Витоки відповідної тенденції містяться в законі С.О. Карцевського, за яким знак і значення не покривають один одного повністю: той самий знак виконує декілька функцій, а те саме значення передають декількома знаками [2].

Принципова асиметричність слова (на відміну від речення), закріплена в моделях як семантичного трикутника (Г. Фреге [32], Ч. Огден, А. Річардс [33]), так і семантичного чотирикутника 
(В.М. Лейчик, А.В. Соколов), позначає відношення між: 1) референтом / денотатом / екстенсіоналом; 2) поняттям / сигніфікатом / інтенсіоналом; 3) лексичним значенням; 4) фономорфологічною формою мовного знака [4, с. 103; 5, с. 105-106].

Це зумовлює гнучкість мовної знакової системи на фоні інших семіотичних систем унаслідок дії двох протилежних тенденцій: 1) до рівноваги, статичності елементів іiї будови (симетрія планів вираження і змісту); 2) до мобільності, динамічності у процесі функціювання (асиметрія планів вираження і змісту) [6].

Спираючись на концепцію лінгвістичної теорії значення М.В. Нікітіна, С.П. Денисова пропонує розглядати знакове значення як: «1) лінгвогносеологічну категорію, що відбиває взаємоіндуковані відношення між означуваним і означувальним у процесі становлення мовного знака як слова (одиниці лексико-семантичної системи мови); 2) елемент знакової репрезентації або відношення між складниками семіозису (знак, денотат (предмет, який позначається), сигніфікат (поняття), мовець, слухач); 3) специфіку знакового значення слова, що $\epsilon$ результатом взаємоіндукованих відношень двох типів: 1) між означуваним і означувальним; 2) між такими складниками семіозису, як знак, денотат, сигніфікат, мовець, слухач, знакова ситуація» [7, с. 8-9].

Отже, актуальність пропонованої наукової розвідки полягає в подальшому розвитку основних положень мотивології в аспекті лінгвосеміотики та лексичної семантики, що потребує детальнішого аналізу мотивації мовних одиниць як співвідношення мовного знака та значення.

Відповідна наукова проблема детермінує уточнення поняття мовного знака, висвітлення його основних характеристик, зокрема в аспекті асиметрії та знакового значення у співвідношенні із внутрішньою формою слова.

Аналіз останніх досліджень i публікацій. Поняття мотивації виникло у словотворі як відповідник формальної та семантичної похідності слів $[8$, с. 401$]$. Такий підхід панував майже до кінця $\mathrm{XX}$ ст. Зокрема, починаючи з 80-х рр. XX ст. у мовознавстві об'єкт словотвору поступово, особливо після праць Г.Й. Винокура [9, с. 427] та В. В. Виноградова [10, с. 198], пересувається у сферу одиниць лексичного рівня. Словотвір стає наукою про слова особливого типу - мотивовані $[11$, c. $346-347 ; 12$, с. $21 ; 13$, с. 18$]$, незважаючи на те, що окремі питання лексичної епідигматики та словотвору певною мірою збігаються [14].

Із подальшим розвитком досліджень у галузі дериватології виникла потреба розмежування умотивованості та похідності, особливо у процесі синонімізації термінів «утворене», «похідне», «мотивоване», «виведене», які зазвичай вжива- ють як дериватологи, так і лексикологи без спроб їхньої диференціації [15].

На думку О. Селіванової, мотивацію варто розглядати у трьох аспектах: 1) у словотвірному - це процес формування семантичного та формального зв'язку похідного слова із твірним у межах знакового коду мовної системи; 2) у номінативному - це формальний і семантичний зв'язок між словами як знаками (план вираження) та їхніми означуваними (план змісту), що встановлюють при творенні слів; 3) у лінгвокогнітивному «наскрізна у процесі творення номінативної одиниці лінгвопсихоментальна операція встановлення семантичної й формальної залежності між мотиватором і похідною номінативною одиницею (мотивованим знаком) на підставі зв'язків різних компонентів структури знань про позначуване в етнічній свідомості» [8, с. 401].

Загальне розуміння мотивації пов'язують із працями О.О. Потебні та його послідовників, зокрема зі вченням про внутрішню форму слова $[16$, c. 98]. Важливим є твердження О.О. Потебні про те, що внутрішня форма містить у собі тільки одну ознаку, тому всяке попереднє слово може бути названо внутрішньою формою наступного. Ця думка перегукується 3 основними положеннями теорії семіологічного означування, відповідно до якої означення мовного знака у хронотопі відбивається у глибинних і поверхневих структурах лексичного рівня. До глибинних структур лексичного рівня відносять план змісту (поняттєве / лексичне значення), до поверхневих - план вираження / зовнішня форма слова. План змісту та план вираження поєднуються через внутрішню форму, або мотиваційне значення [27].

Виокремлення не вирішених раніше частин загальної проблеми. Проблему мотивації мовних одиниць трактують, спираючись на поняття мовного знака. Незважаючи на те, що поняття довільності / недовільності, умотивованості / неумотивованості мовного знака вже розглядали в мовознавчій літературі $[6 ; 7 ; 17 ; 18]$, єдиної думки щодо них немає. Певною мірою це зумовлено специфікою власне мовного знака, зокрема його асиметричною природою, бо будь-які фактори, що викликають зміни, завжди призводять до зсуву відношень між означуваним і означувальним.

У мовознавчій науці тривалий час вважалося $[7 ; 14 ; 15 ; 18]$, що значення обов'язково передбачає знак, тобто будь-яка значуща ситуація $є$ знаковою. Справді, немає знака без значення, але можливі незнакові значущі ситуації. Значення ширше за обсягом, ніж знак. Як відомо, знак є знаком лише тоді, коли має відношення до чогось поза знаком, що й буде значенням знака.

Постановка завдання. Мета нашого дослідження - проаналізувати поняття мотивації 
мовних одиниць як співвідношення мовного знака та значення. Реалізація поставленої мети передбачає передусім уточнення поняття мовного знака, висвітлення його основних характеристик, зокрема в аспекті асиметрії та знакового значення у співвідношенні із внутрішньою формою слова.

Виклад основного матеріалу дослідження. Специфіка мовного знака відображена в таких його властивостях: 1. Мовні знаки відрізняються від знаків інших семіотичних систем тим, що вони в системі мови або мовлення є базою для породження нових знаків. Новий знак $є$ результатом асиметричного розвитку означувального, означуваного та знакової функції. 2. Мовні знаки, на відміну від інших знакових систем, не лише маніфестують інформацію, але й беруть активну участь у іï породженні, тобто формують поняття для цієї інформації. 3. Сфера їх поширення не обмежена й охоплює всі ділянки людської діяльності, тобто вони є засобом когнітивного освоєння дійсності. 4. Означуване мовних знаків завжди детерміноване певною предметною співвіднесеністю. Вони самі матеріальні, тобто мають звукову оболонку. 5. Оскільки відношення людини до пізнаваного предмета $\epsilon$ непрямим, а опосередкованим, то таким посередником $€$ звуковий образ мовного знака. Усе це дає змогу розглядати форми всесвіту як первинну матерію, що є причиною і стимулом до виникнення мовного знака, унаслідок чого звукові образи мовних знаків визначають як похідні, вторинні [14].

С.П. Денисова виділяє такі ознаки мовного знака: 1) соціальність відтворення і спроектованість на екран суспільного життя; 2) чуттєве сприймання як матеріальної одиниці; 3) субститут іншого (первинного) предмета; 4) зовнішня (відношення знака як сукупності звучання і значення до означуваного предмета) та внутрішня співвідносність (відношення між означувальним i означуваним), тобто об'єктивний світ речей, означувальний і означуваний, вступають у певні відношення: 1) позначення (між об'єктивним світом та означуваним); 2) відображення (між об'єктивним світом і означувальним); 3) вираження (між означувальним та означуваним) [7].

Знакові відношення у слові багатоступеневі, тобто фонетичне слово - знак смислу / сигніфіката, останнє разом із першим - знак денотата / референта, а у вислові весь семантичний чотирикутник може бути знаком іншого предмета, зокрема семантичні відношення лексичних одиниць до денотата можуть перетворюватися на внутрішньомовні відношення [7]. Отже, знакове значення - це співвідношення поняття iз фономорфологічною формою слова, оскільки мовне значення взагалі - це концепт, пов'язаний знаком.
Вирізнення у семантичному чотирикутнику позамовного (сфери поняття) i мовного (сфери лексичного значення) пояснює різноманітність підходів до визначення типів семантичних знакових відношень: 1) між знаком і предметом, який позначуваний цим знаком, тобто референтом як конкретним предметом у конкретній ситуації; 2) між знаком і людиною, котра використовує цей знак (прагматичні відношення); 3) між знаком та іншими знаками (внутрішньолінгвістичні значення мовних знаків) [7].

«Слово як результат гносеологічного процесу відбиває єдність сторін семантичного чотирикутника, тому лексико-семантичні трансформації знакового значення слова пов'язані з категорійністю та релятивністю / відносністю, їх визначають також на основі типів взаємодії мовного знака та значення» [7, с. 9]. Таке визначення майже повністю відповідає наведеним нами вище характеристикам мовного знака.

Асиметричні відношення у словесному знакові можуть бути трьох типів: 1) одному означуваному відповідає один означувальний - нульова асиметрія; 2) одному означуваному відповідає декілька означувальних - синтагматична асиметрія; 3) декільком означуваним відповідає один означувальний - парадигматична асиметрія.

Отже, за С.П. Денисовою, основні категорії лексичної семантики представлені такими типами: I - симетричні відношення - моносемічна монолексія (однозначні слова, зокрема термінологічна лексика); II - асиметричні відношення - полісемічна монолексія (багатозначні слова й омоніми) та моносемічна полілексія (сигніфікативна синонімія) [7].

Наслідки асиметрії словесного знака такі: 1. Відносний характер лексичного значення: діахронічна відносність (змінність значення в часі) та синхронічна відносність (контекстуальна залежність значення). 2. Відсутність паралелізму між планами вираження та змісту породжує різноспрямованість тенденцій у функціюванні словесного знака ономасіологічного та семасіологічного характеру. 3. Наявність ізоморфних кореляцій між мікросистемою полісеманта й макросистемою лексики. 4. Існування явища експліцитних / імпліцитних мовних елементів. Експліцитність пов'язана із планом вираження, а імпліцитність - iз планом змісту. Імпліцитність заснована на імплікаційних зв'язках периферійних сем і репрезентована за допомогою категорій пресуппозицій, підтексту, фонових знань, семантичної компресії, універбації, латентних категорій тощо. 5. Динамічний аспект асиметрії словесного знака відбиває сутність мовних змін: зміст змінюється швидше, ніж форма. Унаслідок того, що форма знака відповідає не лише своєму основному значенню, 
але і значенню інших слів у певних контекстуальних умовах, між означуваним і означувальним існує певний проміжок. Збільшення цього проміжку сприяє розвитку багатозначності. Спостерігають асиметрію між знаком і його оточенням, що веде до розрізнення автосемантії (іменники) та синсемантії (переважно ознакові слова). 6. Виділення за аналогією двох неоднакових за обсягом і значимістю зон: центру та периферії, - у мікросистемах словесного знака, зокрема денотата й сигніфіката, полісеманта, макросистеми лексики. 7. Асиметрія між мовним і мовленнєвим планами внаслідок актуалізації лексичного значення, а також подвійної та потрійної актуалізації в тексті [19].

До того ж існує потреба окремо вирізняти явища симетрії / асиметрії безпосередньо серед елементів лексико-семантичного рівня, зокрема у визначенні симетричності білатерального лексичного знака моносемічної лексикальної одиниці або асиметричності між гіперлексемою та лексико-семантичним варіантом.

Через цю асиметрію у природній мові структура та іiі реалізація не збігаються. Кожна мовна одиниця обов'язково має власний потенціал реактивності, неоднаковий за рівнями ієрархічних відношень, і визначає симетричність / асиметричність діалектично пов'язаних послідовностей у мовному континуумі.

Симетричність спостерігають, коли не відбуваються кількісні зміни за якісних змін і навпаки, асиметричність - у випадках, коли якісні зміни викликають кількісні й навпаки. Особливо це важливо за синхронного вивчення значеннєвого обсягу слова, який виступає на фоні всієї сукупності значеннєвих співвідношень. Слово розглядають як член змістової єдності мови загалом [20].

Відкритий характер лексичних структур, асиметрична системність лексичного значення як результат стихійної класифікації явищ розширює системно-структурне поле лексичних одиниць через синтагматичні та парадигматичні відношення. Значна частина повнозначних слів взагалі може не входити до структури будь-якого поля або семантичного ряду, хоча вони й не позбавлені системно-структурних зв'язків з іншими елементами лексико-семантичного рівня.

Звідси випливає проблема визначення ієрархічних відношень семантичних рядів [21], а також лексико-семантичного потенціалу окремого слова, системно-структурні властивості якого розглядають у багатьох аспектах: системному, структурному, функційному, динамічному, зіставному тощо.

3 погляду лексичної семантики найбільш перспективними $є$ такі: 1) структурний - розбіжність між означуваним і означувальним; 2) системний ядерно-периферійна структурація мовних елемен- тів; 3) зіставний - розбіжності між десигнатами у різних мовах; 4) універсалогічний - досліджують такі універсалії, як «означуване - означувальне», «центр - периферія».

Розрізнювальні властивості знака не вичерпують його самого й не зливаються 3 ним. Так, синтагматика може бути певним чином сумісною 3 парадигматикою, а синхронія - 3 діахронією. Сполучення знаків у синтагматиці розглядають як симетричне, обернене, а парадигматику не виводять цілком із синтагматики, тобто синтагматичні послідовності однакових елементів не мають оберненого, симетричного характеру.

Ці факти пояснюють тим, що існує не лише просторова лінійність означуваного (за Ф. де Соссюром), а й часова лінійність, спрямованість і просторова послідовність мовлення у хронотопі, тобто кодувальна структура історично змінна в часі, а діалектально - у просторі.

Таку динаміку відрізняють від динаміки функціювання мови - здебільшого змінним $є$ часовий параметр, проте ним не можна обмежити всі зміни в мові. Мовні знаки репрезентують динаміку існування мови в синхронному плані, а сама кодувальна структура, забезпечуючи потенційну можливість виникнення всіх мовних знаків певної мови, репрезентує статику мови в синхронному плані.

Першим кроком у розв'язанні цього питання $\epsilon$ розрізнення ізотопічних мовних одиниць (з однаковими значеннями та властивостями в тій самій позиції в певному континуумі незалежно від фономорфологічного складу) та ізоморфних мовних одиниць (з однаковою комбінаторною будовою).

На думку Е.М. Медникової, у центрі цієї проблеми стоїть насамперед питання тотожності / розбіжності семантичних обсягів слів [22]. Тотожність пов'язують із кількісними інтегрувальними ознаками. Це переважно явище полісеміі / синонімії. Розбіжність визначають як якісні диференційні ознаки (зіставлення за поняттєвим або граматичним смислом).

Якісні параметри встановлюють згідно 3 притаманними логіці чотирма типами відношень (такими як збіг, вкладення, пересічення і відсутність спільної частини). На цій основі виділяють такі типи відношень між лексичними одиницями за формою та змістом: 1) повний збіг; 2) частковий збіг (поєднує вкладення та пересічення); 3) відсутність збігу [7].

Значеннєве зіставлення здійснюють на рівні семантичних варіантів (за тлумачними словниками), а формальне - за значущими елементами нефонетичних рівнів. Між означувальними існують такі формальні відношення: 1) гетеролексія - повна розбіжність; 2) паралексія - наявність 
спільних елементів; 3) омолексія - повний збіг. Між означуваними такі: 1) гетеросемія - повна розбіжність; 2) парасемія - частковий збіг; 3) омосемія - повний збіг [23-26].

С.П. Денисова пропонує модифікувати наведену класифікацію на основі того, що категорії лексичної семантики одночасно належать і семантичній структурі - одній з окремих субструктур загальної структури мови, - і рівню лексики [7]. Як семантичні категорії вони базуються на семасіологічних ознаках, а як категорії лексичного рівня мають також формальне вираження, тобто категоріям лексичної семантики властиве змістовно-формальне відбиття.

Оскільки основною проблемою семасіології $є$ значення, а ономасіології - найменування / форма, то відповідно до цього провідними поняттями цих наук $є$ полісемія і синонімія / полілексія. На думку С.П. Денисової, ці питання потребують розгляду взаємовідношень між знаком і значенням ще й із позицій семасіології та ономасіології [7].

За семасіологічно спрямованою асиметрією знака та значення виділяють три ступені омосемії: 1) омосемію I ступеня спостерігають, коли знак $i$ значення перебувають у симетричних відношеннях, тобто при моносемії / монолексії; 2) омосемію II ступеня, що властива асиметричним відношенням, коли зв'язок між знаком і значенням досить вільний: знак набуває великої значеннєвої насиченості, а значення одержують широку можливість синонімізації - це парасемія / полілексія; 3) омосемію III ступеня розуміють як межу варіювання багатозначного слова, коли зовнішньо подібні знаки мають семантично не пов'язані значення, - це асемія / омолексія. В ономасіологічному аспекті: 1) омосемія I ступеня властива моносемічній монолексії; 2) омосемія II ступеня парасемічній полілексії; 3) омосемія III ступеня асемічній омолексії [7].

В основу вивчення категорій лексичної семантики покладено універсалію «асиметрія між означуваним і означувальним». Дія цієї універсалії на лексико-семантичному рівні виражена через співвідношення планів вираження і змісту у вигляді синтагматичної та парадигматичної асиметрії.

Отже, основні категорії лексичної семантики об'єднуються у такі типи: I - моносемічна монолексія (однозначні слова, зокрема термінологічна лексика) - симетричні відношення; II - полісемічна монолексія (багатозначні слова й омоніми) і моносемічна полілексія (сигніфікативна синонімія) - асиметричні відношення.

3 позиції співвідношення словесного знака й лексичного значення категорії лексичної семантики визначають в аспекті топологічної / диференційної лінгвістики. Ототожнення реалізацій словникових значень здійснюють за означуваль- ним, оскільки звукова / графічна форма мовного знака - це те інваріантне, що зберігає його матеріальну тотожність. Тотожність (близькість) пов'язана 3 кількісними інтегрувальними ознаками. Відмінність встановлюють за допомогою якісних диференційних ознак (зіставлення за поняттєвим або граматичним смислом): подібність, еквівалентність. Отже, типи формально-семантичних транспозицій знакового значення слова визначають на основі поняття про принципову асиметричність відношень між знаком і значенням. Ці відношення можуть бути трьох типів: 1) нульова асиметрія, коли одному означуваному відповідає один означувальний; 2) синтагматична асиметрія, коли одному означуваному відповідає декілька означувальних; 3) парадигматична асиметрія, коли декільком означуваним відповідає один означувальний.

Проте структурний підхід до значення ще повністю не відповідає на питання взаємозумовленості знака та значення. Останне в сучасних дослідженнях потрактовано як явище духовного плану - інформаційну залежність концептів двох речей у свідомості [27]. Значення виникає тоді, коли існують концептуальні зв'язки певного виду, що поєднують концепти як дискретні змістові сутності свідомості. Ці зв'язки можуть бути імплікаційними, порівняльно-класифікаційними та семіотичними (знаковими).

Імплікаційні зв'язки - це розумовий аналог реальних зв'язків сутностей об'єктивного світу. Імплікацію в цьому аспекті розглядають як один із основних засобів організації свідомості, формування концептуальних структур. Імплікаційні зв'язки породжують значення через актуалізацію інформаційно важливого концепту, який унаслідок цього виконує функцію значення іншого концепту, пов'язаного з актуалізованим.

До концептуальних зв'язків, що структурують свідомість, відносять також порівняльно-класифікаційні, які розглядають як розумовий аналог розподілу ознак у сутностях світу. Ці загальні ознаки можуть бути декількох типів: 1) інтенсіональні, тобто класотвірні, за родо-видовою ієрархією понять; 2) еквонімічні, тобто узагальнювальні, за видо-видовим зв'язком понять; 3) симілятивні, тобто порівняльні, за уподібненням ознак.

Важливо, що порівняльно-класифікаційні (метафоричні) зв'язки, базовані на спільності ознак, не породжують нового значення, оскільки встановлений зв'язок між двома сутностями відображає не якийсь реальний зв'язок, а лише спільність ознак або рівні узагальнення ознак. Семіотичні (знакові) концептуальні зв'язки вказують на взаємовідношення між двома сторонами знака - означувальним та означуваним. На відміну від імплікаційних, знакові зв'язки призначені для 
актуалізації закріпленого значення, а не того, що випливає із ситуації.

Це дає підстави М.В. Нікітіну виділити два типи значення: 1) імплікаційне (незнакове); 2) семіотичне (знакове, конвенційне, кодифіковане) [27]. Кожний знак несе значення обох типів. Оскільки джерелом (імплікатором) актуалізованого (вживаного) знака $є$ подія-знак, то цей різновид імплікаційних значень називають семіоімплікаційними. Сам знаковий акт служить джерелом позазнакових імплікацій, які несуть різноманітну інформацію, що може доповнювати власне знакове значення висловів, ускладнювати його, корегувати тощо. Одержувач інформації має своєрідний наслідок взаємодії кодифікованого семіотичного й некодифікованого семіоімплікаційного значення знакових актів як синтез знання мови, знака, світу, хоча чіткої межі між ними не існує. Кодифіковане семіотичне значення у процесі реалізації стає джерелом імплікацій, нарощуючи сумарне значення знакового акту, тому що будь-яка знакова подія є подією не лише в галузі знакової діяльності, але й у світі загалом.

Імплікаційна залежність речей і подій стає знаково-значущою тоді, коли вона виступає як навмисно інформаційно-комунікативна дія (акт), тобто повинен існувати відправник інформації, який може вилучати річ-імплікатор і замінювати ii iншим субститутом. Так виникають символи. Знаку передує конвенція про значення, він потребує значення мови. Значення ширше за знак, оскільки значення виникає не лише внаслідок знання мови, але і внаслідок знання світу. Справжній знак передбачає як одержувача інформації, так і відправника, які володіють спільною мовою.

Оскільки знак позначений інтенціональністю, тобто прагненням реалізувати інформаційно-комунікативний намір відправника повідомлення знак сприяє актуалізації у свідомості спостерігача пов'язаних із ним імплікацій, тому існують проміжні градації посилення знаковості: 1) дознаковий рівень одержання значень за умов ланцюжкової залежності двох подій, коли перша подія інформує інтерпретатора про другу; 2) знаковий рівень за умов знакової ситуації, коли спочатку формується символічне значення 3 опорою на імплікаційні зв'язки, а потім - принципово умовне значення. Проте навіть ставши знаком, він не позбавлений повністю своєї речової природи, субстанціональної основи знакової функції речі, тобто знак продовжує бути джерелом імплікаційних (семіоімплікаційних) значень. Такі значення не кодифіковані й залежать від конкретного вживання знака. Встановлюючи значення таких знаків, треба спиратися насамперед на знання про світ, а не про мову.

Предмет семіотики - систематизація знаків і знакових систем різного роду. До помилок сучас- ної семіотики належать, на думку М.В. Нікітіна, широке розуміння знака (треба вилучати індексальність та іконічність) і ототожнення знака та значення за обсягом. У зв'язку з цим потрібно відмовитися від розгляду імплікаційних значень у семіотиці та нерозрізнення імплікаційного й знакового видів значення (тобто функційної, власне знакової та субстанціональної, речової сторін), що призводить до змішування двох принципово відмінних видів значення знаків: конвенційного й (семіо)імплікаційного. Зміни у значенні слова зумовлені різними причинами. Одна з них - забування внутрішньої форми. Мова прагне усунути неадекватність слова, яка виникла внаслідок того, що в основу найменування покладена одна ознака, а не їхня сукупність, як у дійсності.

У мові виділяються три види семантичних значимостей: 1) граматичне значення словозмінних і словотвірних кореневих морфем; 2) лексичне значення різних семіологічних класів; 3) смисл вторинного означування усіх синтагматичних одиниць. Один щодо одного мовні знаки виконують три основні функції: 1) розрізнювальну; 2) конструктивну; 3) класифікувальну. Щодо об'єктів і елементів свідомості функції знаків мови інші. Головні 3 них такі: 1) номінативна називає об'єкт; 2) дейктивна - вказує на нього; 3) експресивна - висловлює стан свідомості; 4) сигніфікативна - позначає поняття; 5) моделювальна - утворює знаковий аналог ситуації; 6) прагматична - впливає на людину. У внутрішньосистемному аспекті мовні знаки виконують три функції: розрізнювальну, конструктивну, класифікувальну; а в зовнішньосистемному - номінативну, дейктивну, експресивну, сигніфікативну, моделювальну, прагматичну.

Отже, важливою характеристикою знака $є$ його подвійна належність до певної знакової системи й до позначуваного. Ця закономірність відображає залежність між людиною, кодом і позакодовою реальністю.

Як відомо, одним з основних положень лінгвістичної теорії Ф. де Соссюра є принцип довільності мовного знака [28]. Довільність Соссюр трактував насамперед як неумотивованість, тобто як відсутність зумовленого природою речей зв'язку між означувальним і означуваним, однак у системі мови мовний знак виявляється відносно мотивованим. Під відносною умотивованістю мовного знака Соссюр розумів часткову умотивованість за утворення словесних знаків, ті обмеження, які накладає на них словотворча система, умотивованість складних і похідних слів. Саме це, на його думку, дає підстави певною мірою упорядкувати та систематизувати мовні елементи. Крім того, наслідком загального положення про довільність мовного знака Ф. де Соссюр вважав потенційну 
можливість зрушення відношень між відносно відокремленими один від одного означувальним та означуваним.

Усупереч поглядам Ф. де Соссюра, нині панує положення, згідно $з$ яким мовний знак довільний у тому сенсі, що зв'язок означувального й означуваного не зумовлений їхніми внутрішніми відношеннями: у різних мовах ідентичні поняття виражені різними акустично-зоровими сигналами [29]. Водночас у кожній мові деякі знаки є відносно мотивованими, тобто їхне значення зумовлене словами, з яких вони складені або з якими їх асоціюють [30; 31].

В.В. Виноградов писав, що умотивованість значень слів зв'язана з розумінням їхньої будови, 3 живим усвідомленням семантичних відношень між словесними елементами мовної системи $[20$, c. 9]. На його думку, розходження між мотивованими і неумотивованими словами зумовлені не тільки граматичними, але і лексико-семантичними зв'язками слів, тобто тим, що $є$ внутрішньою формою слова, яку, за В. фон Гумбольдтом, O.О. Потебнею та іншими, називають способом репрезентації значення у слові, способом поєднання думки зі звуком.

Внутрішня форма слова зумовлена системою розуміння світу, яка притаманна сучасному стану матеріальної та духовної культури конкретних носіїв мови, оскільки в контексті останньої виникло чи перетворилося певне слово чи сполучення слів. Саме цим В.В. Виноградов пояснює історичну мінливість внутрішньої форми [20, с. 9-45].

Вплив внутрішньої форми на актуалізацію експресії в мовному знакові В.В. Виноградов, за Ш. Баллі, пов'язує із боротьбою двох тенденцій у мові - експресивної та аналітичної. Перша збагачує мову конкретними елементами, продуктами афектів і суб'єктивізму мовця, створюючи нові слова та вирази; друга - усуває емоційні елементи, уточнюючи думку й намагаючись мати одне вира- ження для кожної окремої функції та тільки одну функцію для кожного вираження.

Внутрішня форма слова найяскравіше реалізована у стилістичній характеристиці мовного знака, оскільки стилістичну сутність слова визначає його індивідуальне місце в семантичній системі мови, у колі його функційних і жанрових різновидів. У цьому разі внутрішня форма слова зумовлює індивідуальну характеристику слова залежно від попередньої мовної традиції, а також від сучасного співвідношення значеннєвих елементів у мовній системі та їі стильових різновидах.

Висновки. На сучасному етапі розвитку лінгвістичної науки мовний знак як акумулятор результатів ментальної діяльності людини характеризується за допомогою властивостей, що випливають зі взаємозв'язку мови і мислення, а також сформувалися у процесі реальної історичної практики функціювання природних мов. Серед основних рис мовного знака, враховуючи його асиметрію та знакове значення у співвідношенні i3 внутрішньою формою слова, можна виокремити такі, як: 1) цілісність матеріально-ідеальної природи знака, тобто єдність означувального й означуваного; 2) відносна умотивованість, яка виявляється через внутрішню форму (особливо у процесі первинного семіозису) у вигляді того психофізіологічного зв'язку, що існує між матеріальною оболонкою слова та поняттям про нього; 3) довільність (відносна умотивованість) щодо обрання ознак, які покладені в основу внутрішньої форми; 4) диференційованість, що виявляється через його відмежованість від контексту; 5) немінливість (відносна мінливість в історичному часі); 6) лінійність.

У подальших наукових дослідженнях буде схарактеризовано особливості когнітивної основи термінів-зоонімів у семасіологічному й ономасіологічному аспектах.

\section{ЛITEPATУРA}

1. Гак В.Г. Семантическая структура слова как компонент семантической структуры высказывания. Семантическая структура слова. Москва : Наука, 1977. С. 78-96.

2. Карцевский С О. Об асимметрическом дуализме лингвистического знака. Звегинцев В.А. История языкознания XIX-XX вв. в очерках и извлечениях. Москва : Просвещение, 1965. Ч. 2. С. 85-90.

3. Кретов А.А. Ассиметрия в лингвистике. Вестник ВГУ. Серия: Лингвистика и межкультурная коммуникация. 2010. № 2. С. 5.

4. Лейчик В.М. Терминоведение. Предмет, методы структура. Москва : КомКнига, 2005. 256 с.

5. Соколов А.В. Введение в теорию социальной коммуникации: учеб. пособ. Санкт-Петербург : СПбГУП, 1996. 320 с.

6. Городецкий В.Ю. К проблеме семантической типологии. Москва : Изд-во Московского государственного университета, 1969. 564 с.

7. Денисова С.П. Типологія категорій лексичної семантики. Київ : КНЛУ, 1995. 286 с.

8. Селіванова О. Сучасна лінгвістика : термінологічна енциклопедія. Полтава : Довкілля-К, 2006. $716 \mathrm{c.}$

9. Винокур Г.О. Избранные работы по русскому языку. Москва : Учпедгиз, 1959. 492 с. 
10. Виноградов В.В. Словообразование в его отношении к грамматике и лексикологи. Избранные труды. Исследования по русской грамматике. Москва : Наука, 1975. 559 с.

11. Кубрякова Е.С. Словообразование. Общее языкознание. Внутренняя структура языка. Москва : Наука, 1972. С. 346-347.

12. Зверев А. Д. Словообразование в современных восточнославянских языках. Москва : Высшая школа, 1981. $206 \mathrm{c.}$

13. Ширшов И.А. Множественность словообразовательной мотивации в современном русском языке. Ростов, 1981. $117 \mathrm{c}$.

14. Улуханов И.С. Мотивация в словообразовательной системе русского языка. Москва : Азбуковник, 2005. $313 \mathrm{c}$.

15. Голев Н.Д. Введение в теорию и практику мотивацинного и структурного анализов : учебное пособие. Барнаул : АГУ, 1981. 87 с.

16. Потебня А.А. Мысль и язык. Потебня А.А. Слово и миф. Москва : Правда, 1989. 282 с.

17. Кудрявцева Л.А. Моделирование динамики словарного состава языка : монография. Киев : ИСДОУ, 1993. $280 \mathrm{c}$.

18. Соломоник А. Язык как знаковая система. Москва : Наука, 1992. 223 с.

19. Языковая номинация. Общие вопросы. Москва : Наука, 1977. 359 с.

20. Виноградов В.В. Русский язык. Москва : Высшая школа, 1972. 614 с.

21. Конецкая В.П. О системности лексики. Вопросы языкознания. 1984. № 1. С. 26-36.

22. Медникова Э.М. Значение слова и методы его описания. Москва : Высш. шк., 1974. 202 с.

23. Бережан С.Г. Отражение семантических системных связей лексических единиц в одноязыковом (толковом) словаре. Словарные категории : сборник статей / отв. ред. Ю.Н. Караулов. Москва : Наука, 1988. С. 5-15.

24. Бережан С.Г. Семантическая эквивалентность лексических единиц. Кишинев : Штиинца, $1973.372 \mathrm{c}$.

25. Бережан С.Г. Совпадение отдельных элементов смысловой структуры слова как основа синонимичности. Изв. АН СССР. Серия литературы и языка. 1967. Т. XVI. № 3. С. 254-263.

26. Бережан С.Г. Теория семантических полей и синонимия. Проблемы языкознания. Тезисы докладов и сообщений советских ученых на Х Международном конгрессе лингвистов. Москва : Наука, 1967. C. $165-169$.

27. Никитин М.В. Основы лингвистической теории значения. Москва : Высш. шк., 1988. 168 с.

28. Соссюр де Ф. Курс загальної лінгвістики. Київ : Основи, 1998. 324 с.

29. Кузнецов В.Г. Женевская лингвистическая школа: от Соссюра к функционализму. Москва : Изд-во «УРСС», 2003. $184 \mathrm{c.}$

30. Никитин М.В. Предел семиотики. Вопросы языкознания, 1997. № 1. С. 3-14.

31. Степанов Ю.С. Общее языкознание. Москва : Просвещение, 1975. С. 230-253.

32. Frege G. Über Sinn und Bedeutung. Zeitschrift für Philosophie und Philosophische Kritik. 1892. № 100. S. $25-50$.

33. Ogden C.K., Richards I.A. The Meaning of Meaning, New York, Harcourt, Brace \& World, Inc., 1923.

\section{REFERENCES}

1. Hak V.H. (1977). Semanticheskaia struktura slova kak komponent semanticheskoi struktury vyskazyvaniia [Semantic structure of a word as a component of the semantic structure of an utterance]. Semantic word structure. Moskva : Nauka. P. 78-96.

2. Kartsevskyi S. (1965). Ob asimmetricheskom dualizme lingvisticheskogo znaka [On the asymmetric dualism of a linguistic sign]. Zviegintsev V.A. History of linguistics in the 19th-20th centuries in essays and extracts. Moskva : Prosveshcheniye, 2. P. 85-90.

3. Kretov A.A. (2010). Assimetriia v lingvistike [Asymmetry in linguistics]. VSU Bulletin. Series: Linguistics and Intercultural Communication. № 2. P. 5.

4. Lieichik V.M. (2005). Terminovedeniie. Predmet, metody struktura [Terminology. Subject, methods structure]. Moskva : KomKniga. 256 p.

5. Sokolov A.V. (1996). Vvedeniie v teoriiu sotsialnoi kommunikatsii: ucheb. posob. [Introduction to the theory of social communication: textbook manual]. Sankt Peterburg: SPbGUP. 320 p.

6. Denysova S.P. (1995) Typolohiia katehorii leksychnoii semantyky [Typology of categories of lexical semantics]. Kyiv : KNLU. 286 p.

7. Gorodetskii V.Yu. (1969) K probleme semanticheskoi tipologii [On the problem of semantic typology]. Moskva : Izd-vo Moskovskogo gosudarstvennogo universiteta. $564 \mathrm{p}$. 
8. Selivanova O. (2006). Suchasna linhvistyka: terminolohichna entsyklopediia [Modern linguistics: a terminological encyclopedia]. Poltava : Dovkillia-K. 716 p.

9. Vinokur G.O. (1959). Izbrannyie raboty po russkomu iazyku [Selected works on the Russian language]. Moskva : Uchpedgiz. 492 p.

10. Vinogradov V.V. (1975). Slovoobrazovaniie v iego otnoshenii k grammatike i leksikologii [Word formation in its relation to grammar and lexicology]. Selected Works. Studies in Russian grammar. Moskva : Nauka. $559 \mathrm{p}$.

11. Kubriakova E.S. (1972). Slovoobrazovaniie [Word formation]. General linguistics. Internal structure of the language. Moskva : Nauka. P. 346-347.

12. Zvieriev A.D. (1981). Slovoobrazovaniie v sovremennykh vostochnoslavyanskikh yazykakh [Word formation in modern East Slavic languages]. Moskva : Vysshaya shkola. 206 p.

13. Shyrshov I.A. (1981). Mnozhestvennost slovoobrazovatelnoi motivatsii v sovremennom russkom iyazyke [The plurality of word-formation motivation in modern Russian]. Rostov. 117 p.

14. Ulukhanov I.S. (2005). Motivatsiia v slovoobrazovatelnoi sisteme russkogo iazyka [Motivation in the word-formation system of the Russian language]. Moskva : Azbukovnik. 313 p.

15. Golev N.D. (1981). Vvedeniie v teoriiu i praktiku motivatsinnogo i strukturnogo analizov : Uchebnoie posobiie [An Introduction to Theory and Practice of Motivational and Structural Analysis: A Study Guide]. Barnaul : AGU. 87 p.

16. Potebnia A.A. (1989). Mysl i iazyk [Thought and language]. Word and myth. Moskva : Pravda. 282 p.

17. Kudriavtseva L.A. (1993) Modelirovaniie dinamiki slovarnogo sostava yazyka: Monografiia [Modeling the dynamics of the vocabulary of a language: Monograph]. Kyiv : ISDOU. 280 p.

18. Solomonik A. (1992) Yazyk kak znakovaia systema [Language as a sign system]. Moskva : Nauka. 223 p.

19. Yazykovaia nominatsiia. Obshchiie voprosy [Language nomination. General issues] (1977) Moskva : Nauka. 359 p.

20. Vynohradov V.V. (1972) Russkii yazyk [Russian language]. Moskva : Vysshaya shkola. 614 p.

21. Konetskaya V.P. (1984) O sistemnosti leksiki [About the consistency of vocabulary]. Linguistic issues. № 1. P. 26-36.

22. Mednikova E.M. (1974) Znacheniie slova i metody yego opisaniia [The meaning of the word and methods of its description]. Moskva : Vysshaya shkola. 202 p.

23. Berezhan S.H. (1988) Otrazheniie semanticheskikh sistemnykh sviazei leksicheskikh yedinits v odnoyazykovom (tolkovom) slovare [Reflection of semantic systemic connections of lexical units in a monolingual (explanatory) dictionary]. Vocabulary categories. Moskva : Nauka. P. 5-15.

24. Berezhan S.H. (1973) Semanticheskaia ekvivalentnost leksicheskikh yedinits [Semantic equivalence of lexical units]. Kishinev : Shtiintsa. 372 p.

25. Berezhan S.H. (1967) Sovpadeniie otdelnykh elementov smyslovoi struktury slova kak osnova sinonimichnosti [The coincidence of individual elements of the semantic structure of a word as the basis of synonymy]. News of the USSR Academy of Sciences. Literature and Language Series. Vol. XVI. № 3. P. 254-263.

26. Berezhan S.H. (1967) Teoriia semanticheskikh polei i sinonimiia [Semantic field theory and synonymy]. Problems of linguistics. Abstracts of reports and communications of Soviet scientists at the X International Congress of Linguists. Moskva : Nauka. P. 165-169.

27. Nikiin M.V. (1988) Osnovy lingvisticheskoi teorii znacheniia [Foundations of the linguistic theory of meaning]. Moskva: Vyshaia shkola. 168 p.

28. Sossiur de F. (1998) Kurs zahalnoii linhvistyky [General linguistics course]. Kyiv : Osnovy. 324 p.

29. Kyznetsov V.G. (2003) Zhenevskaia lingvisticheskaia shkola: ot Sossiura k funktsionalizmu [Geneva linguistic school: from Sossiure to functionalism]. Moskva : URSS. 184 p.

30. Nikitin M.V. (1997) Predel semíotiki [Semiotics limit]. Linguistic issues, Vol. 1. P. 3-14.

31. Stepanov Yu.S. (1975) Obshcheie yazykoznaniie [General linguistics]. Moskva: Prosveschenie. P. 230-253.

32. Frege G. (1892). O smysle i znachenii [About meaning and meaning]. Journal for Philosophy and Philosophical Criticism. № 100. S. 25-50.

33. Ogden C.K., Richards I.A. (1923). Znacheniie smysla [The Meaning of Meaning]. New York, Harcourt, Brace \& World, Inc. 